\title{
Scientists, Students, and Crowds: A Collaboration to Improve Health Literacy
}

\author{
Susan M. Abdel-Rahman ${ }^{1, *}$, Nicole McClure Kurlbaum² \& Stan Fernald ${ }^{2}$ \\ ${ }^{1}$ Division of Clinical Pharmacology, Toxicology, and Therapeutic Innovation, Children's Mercy Hospital, Kansas \\ City, MO; Illustration, USA \\ ${ }^{2}$ Illustration Department, Kansas City Art Institute, Kansas City, MO, USA \\ *Correspondence: Division of Clinical Pharmacology, Toxicology, and Therapeutic Innovation, Children's Mercy \\ Hospital, 2401 Gillham Rd., Kansas City, MO 64108, USA. Tel: 1-816-234-3059. E-mail: srahman@cmh.edu
}

Received: June 5, 2017 Accepted: July 10, 2017 Online Published: October 10, 2017

doi:10.5430/wjss.v5n1p1 URL: https://doi.org/10.5430/wjss.v5n1p1

\begin{abstract}
Where language and literacy barriers exist, medical researchers continue to do a poor job of ensuring access to clinical trials. Feedback from key stakeholders suggests that incorporating visual aids into the consent process can facilitate enrollment of neglected populations. This study was initiated to examine whether a collaboration between a teaching hospital and fine arts institution that introduced the topic of health literacy to student artists could be used to generate medical research-related images. Crowdsourcing was used to examine the effectiveness of the illustrations and provide students with feedback from a lay audience. Twenty-five student artists and 184 survey respondents participated in this study. Combined positive ratings of "very" or "fairly" effective ranged from 5-91\% while negative ratings of "slightly" or "not" well ranged from 5-89\%. Collaborations, as explored in this paper, can promote minority awareness and provide a novel mechanism by which to communicate complex research-related concepts to patients with limited literacy.
\end{abstract}

Keywords: medical research, visual arts, permission, assent, consent

\section{Introduction}

Medical researchers continue to do a poor job of providing underserved populations (e.g. children and minorities) access to clinical trials.[Bourgeois, Murthy, Ioannidis \& Mandl, 2012; Lang et al., 2010; Hussain-Gambles, Atkin \& Leese, 2004] While it is easy to appreciate that this oversight disadvantages patients who are denied access to the state-of-the-art treatments received by trial participants, researchers often fail to recognize that the exclusion of special populations from their investigations can limit the generalizability of their findings.[Davis et al., 1985; Heiat, Gross \& Krumholz, 2002]

For many underserved populations, issues of language and literacy interfere with recruitment efforts. Researchers argue that they lack the confidence to effectively explain research-related concepts to these populations or cannot afford the costs associated with employing personnel that can serve as interpreters. Sadly, widespread disparities in health literacy reinforce researchers' concerns.[Lipton et al., 2011] Even when informational materials are presented in a participant's native language, studies suggest that they demonstrate strikingly low comprehension levels for basic research concepts.[Schenker, Wang, Selig, Ng \& Fernandez, 2007; Minnies et al., 2008] For researchers intent on providing all patients with access to clinical trials, they must; ensure that participant enrollment is truly voluntary; confirm that the permission given by patients is genuinely informed; and ensure that the information given to patients complies with federal, state, and local regulations which includes presenting them with concepts that are somewhat nebulous and difficult to communicate.[Code of Federal Regulations 2011]

Recently we investigated whether illustrating consent forms could serve as a suitable alternative for populations where comprehension and literacy present a barrier to effective communication. We solicited feedback from patients (including children), parents of patients, non-English language speakers, researchers, and institutional oversight committees. Nearly every participant $(>93 \%)$ agreed that the illustrated forms effectively addressed elements 
required in the regulations and the majority of individuals representing Institutional Review Boards (83\%) would have approved the illustrated form with little or no modification.[Abdel-Rahman, 2015]

One finding that we, as scientists, were not equipped to address related to comments about the overall quality of the images. Our participants felt that the Clip Art-based pictures we had relied on were rudimentary and unsophisticated. In response, we approached the Kansas City Art Institute (KCAI), one of the largest 4-year colleges of art and design in the country, to explore whether there was a mechanism by which we might engage students to participate in the creative process of translating research-related concepts into visual images. This paper reviews findings from the pilot of this collaboration.

\section{Methods}

\subsection{Artists}

KCAI students enrolled in the Medical Illustration class (typically $3^{\text {rd }}$ and $4^{\text {th }}$ year students) were introduced to issues surrounding health literacy as part of that semesters curriculum. They were subsequently commissioned to develop research-related images as a part of the Institute's Sponsored Studio program which provided tuition remission for their activities. Students worked in self-selected groups that were assigned various concepts for illustration. They used classroom time to discuss their concept and create "thumbnail" images for critique by their peers. Each student developed one thumbnail image into a "rough stage" draft illustration which was subsequently refined to the "sketch for approval" stage in the next class session. The process was repeated over several weeks offering a structured block of activity for the students to engage in the creation of multiple concepts. Given the pilot nature of the project, no restrictions were placed on the students who were permitted to create the images in the style and medium of their choice.

\subsection{Evaluators}

We used a crowdsourcing mechanism to provide students with robust preliminary feedback related to how their illustrations were perceived by the lay public. This strategy permitted us to gather opinions from a large, diverse audience at a substantially lower cost and in a fraction of the time required of the traditional methods such as focus groups. Feedback was solicited using web-based Human Intelligence Task (HIT) services under a protocol that was reviewed and approved by the Institutional Review Board at our hospital. Amazon Mechanical Turk (MTurk) was used to publish the HIT, recruit and compensate participants, and collect the data.

We created an MTurk requestor account to deploy the HITs, each requiring respondents to evaluate 5 images. For each image, respondents were asked:

1) What do you think this picture is trying to say?

2) We are trying to say [concept inserted]. How well does this picture do that?

3) How would you change the picture to better show what we are trying to say?

The first and third questions used an open-ended response format to permit free-text entry. The second question used a 5-point Likert scale to measure response according to the following options; very well, fairly well, somewhat well, slightly well, not well. Questions 2 and 3 were revealed to the respondent only after a response to question one was provided. After reviewing all images in the HIT, a final series of questions captured demographic data about the respondent including; age, gender, level of education, and whether they had any exposure to clinical research. Standard descriptive statistics were used to summarize the MTurk data.

\section{Results}

In total, 25 students were involved in this pilot, 11 in semester one and 14 in semester two. The MTurk respondents numbered 100 in semester one and 84 in semester two. Respondents were predominantly female $(69.6 \%)$ with only a minority indicating that they had prior exposure to clinical research (33.3\%). Distribution across the range of ages from $<20 \mathrm{yr}, 21-29 \mathrm{yr}, 30-39 \mathrm{yr}, 40-49 \mathrm{yr}, 50-59 \mathrm{yr}$, and $60+$ years was $1.1 \%, 17.9 \%, 34.2 \%, 15.8 \%, 21.2 \%$ and $9.8 \%$, respectively. The highest level of education attained by our respondents was middle school in $0.5 \%$, high school in $13.6 \%$, some college in $16.8 \%$, completion of a 2 -year degree in $14.1 \%$, completion of a 4 -year degree in $32.1 \%$, graduate school in $13 \%$, and post-graduate education in $9.8 \%$.

The illustration styles adopted by the student artists ranged from simple icons to colorful cartoons (Figure). A small sampling of responses from the MTurkers, are provided in the Table. Though only a few comments are shown for 
each illustration, the vast majority were objective and constructive, a few were subjective (e.g. cool illustration, it's creepy, spot on, frightening), some were colorful (e.g. aliens are filling your prescriptions, I'm in the middle of an existential crisis), and a few were provocative (e.g. good pic but can these kids tell time?, would work in America but may need to change if used in another country).

This crowdsourcing strategy was robust enough to rank the effectiveness of the images along a wide continuum without clustering at either end of the spectrum. Combined positive ratings of "very" or "fairly" effective ranged from 5-91\%. Combined negative ratings of "slightly" or "not" well ranged from 5-89\% (Table). Notably, integration of Likert scoring into the surveys afforded an objective method for comparing or ranking images depicting the same concept but created by different illustrators. In combination with the subjective open-ended response, we could were able to gain a sense of the stylistic preferences of our respondents.

\section{Discussion}

This pilot project offered a valuable platform for promoting minority awareness and introducing student artists to the issue of health literacy while providing researchers a novel mechanism by which to communicate complex research-related concepts to patients with limited literacy. It also supports the Institute of Medicine's call to develop "innovative mechanisms to promote understanding for participants with language barriers, diminished capacity, and known vulnerabilities" which we strongly believe can be accomplished through partnerships between health care providers and artists.[National Research Council 2002]

Though the quality of the week 1 illustrations provided in the Figure is admittedly mixed, we appreciated an improvement in the quality of the illustrations the student artists produced as they became increasingly comfortable attempting to tackle some relatively nebulous concepts such as voluntariness and confidentiality. This finding reinforced the idea of providing students with an uninterrupted block of time to acclimate to the task. We should note that we gave the students a fair bit of creative freedom during this pilot; however, not all of their artistic choices which met with favorable responses by the reviewers. Subsequent collaborations will aim to provide the students with more structured guidance surrounding the desired end product. We are also exploring tasking the students with the illustration of an entire form, much like a cartoon or graphic novel, rather than isolated concepts. This might provide them with a bit more context and permit the student to "tell the story" for their target patient population.

The intent was to return images to the original artist, along with a summary of the reviews, for subsequent refinement guided by the 1) content analysis of the misinterpretations revealed via the open ended responses to the first question and 2) and suggestions for refinement revealed in the open ended responses to the third question. However, the timing of this project during the course of the semester, as structured in this pilot, did not afford time for a final refinement of the image based on crowd feedback prior to the end of the semester. We feel this can easily be addressed with slight adjustment to the timing of this module in the semester.

A significant limitation with the interpretation of the findings in this study surrounds the terminal education level of our MTurkers which is higher than that of the patient population for whom these images would be intended. Our decision to pursue a "preliminary" evaluation in MTurk was influenced largely by the value of being able to engage art students with rapid feedback that would not be possible using a traditional convenience sampling based design. Illustrations intended for use in our patients will eventually be evaluated in a more representative population using focus groups or one-on-one interviews which we have successfully accomplished in the past by engaging our institution's various family advisory boards which are constituted by children, parents/care givers, and non-English language speakers.[Abdel-Rahman, 2015]

\section{Conclusions}

The collaboration described herein reflects an ideal partnership between a teaching hospital and an institution of higher learning. Based on the observations of this pilot program, we feel that similar collaborations can expand the impact of the visual arts in medical research and, with the necessary validation in patient populations of interest, facilitate access to state-of-the-art medical advances for underserved populations. We also believe that by engaging student artists we can promote the marriage of research and the arts in a new generation of artists while fostering an awareness of the unique challenges faced by low-literacy populations. However, construction of this type of collaboration will require special attention to the proposed layout within their educational curriculum. It will also require structured guidance with respect to the desired end product so as to ensure the application of health literacy principles within their art works. 


\section{Acknowledgements}

This work was supported by the National Endowment for the Arts under Grant number 16-3800-7001.

\section{References}

Abdel-Rahman, S.M. (2015). Evaluating the Effectiveness of an Illustrated Permission/Assent Form. J Immigr Minor Health, 17, 1504-1508. https://doi.org/10.1007/s10903-014-0116-6.

Bourgeois, F.T., Murthy, S., Ioannidis, J.P.A., \& Mandl, K.D. (2012). Clinical Drug Trials: A Paucity of Pediatric Representation Mismatched to Global Disease Burden [abs]. PAS meeting, Boston, MA.

Code of Federal Regulations. (2011). Protection of Human Subjects - Elements of Informed Consent, 21 C.F.R. pt. 50.25 .

Davis, S., Wright, P.W., Schulman, S.F., Hill, L.D., Pinkham, R.D., Johnson, L.P., Jones, T.W., Kellogg, H.B., Radke, H.M., Sikkema, W.W., Jolly, P.C., \& Hammar, S.P. (1985). Participants in prospective, randomized clinical trials for resected non-small cell lung cancer have improved survival compared with nonparticipants in such trials. Cancer, 56(7), 1710-1718.

Heiat, A., Gross, C., \& Krumholz, H. (2002). Representation of the elderly, women, and minorities in heart failure clinical trials. Arch Int Med, 162(15), 1682-1688.

Hussain-Gambles, M., Atkin, K., \& Leese, B. (2004). Why ethnic minority groups are under-represented in clinical trials: a review of the literature. Health Soc Care Community, 12(5), 382-388. https://doi.org/10.1111/j.1365-2524.2004.00507.x

Lang, T.A., White, N.J., Tran, H.T., Farrar, J.J., Day, N.P., Fitzpatrick, R., Angus, B.J., Denis, E., Merson, L., Cheah, P.Y., Chilengi, R., Kimuati, R., \& Marsh, K. (2010). Clinical Research in Resource-Limited Settings: Enhancing Research Capacity and Working Together to Make Trials Less Complicated. PLoS Negl Trop Dis, 4(6), e619. https://doi.org/10.1371/journal.pntd.0000619

Lipton, L.R., Santoro, N., Taylor, H., Kidwai, N., Isaac, B., Magnani, M., \& Pal L. (2011). Assessing comprehension of clinical research. Contemp Clin Trials, 32(5), 608-613. https://doi.org/10.1016/j.cct.2011.04.014

Minnies, D., Hawkridge, T., Hanekom, W., Ehrlich, R., London, L., \& Hussey, G. (2008). Evaluation of the quality of informed consent in a vaccine field trial in a developing country setting. BMC Med Ethics, 9, 15. https://doi.org/10.1186/1472-6939-9-15

National Research Council. (2002). Responsible Research: A Systems Approach to Protecting Research Participants. Washington, DC: The National Academies Press. Pp 123-127.

Schenker, Y., Wang, F., Selig, S.J., Ng, R., \& Fernandez, A. (2007). The impact of language barriers on documentation of informed consent at a hospital with on-site interpreter services. Journal of General Internal Medicine, 22(Suppl 2), 294-299. https://doi.org/10.1007/s11606-007-0359-1 
Table 1. MTurker Objective and Subjective Impressions of Student Illustrations

\begin{tabular}{|c|c|c|c|c|c|}
\hline Image & Concept & $\begin{array}{l}\% \text { very or } \\
\text { fairly well }\end{array}$ & $\begin{array}{c}\% \text { slightly } \\
\text { or not well } \\
\text { at all }\end{array}$ & $\begin{array}{l}\text { Example Responses: } \\
\text { What do you think this picture } \\
\text { is trying to say? }\end{array}$ & $\begin{array}{l}\text { Example Responses: } \\
\text { How would you change the picture to better } \\
\text { show what we are trying to say? }\end{array}$ \\
\hline 1 & $\begin{array}{l}\text { You should not to } \\
\text { eat or drink } \\
\text { any-thing after } \\
\text { midnight on the } \\
\text { day of your study } \\
\text { visit }\end{array}$ & 91 & 9 & $\begin{array}{l}\text { Do not eat or drink after a } \\
\text { certain time of the night. } \\
\text { No eating or drinking after } \\
\text { midnight. } \\
\text { Take this medication at } \\
\text { midnight with no water or } \\
\text { food. }\end{array}$ & $\begin{array}{l}\text { - You could add numbers to the clock or } \\
\text { silverware next to the plate/on a table. } \\
\text { I'd clean the drawings up a little bit so that } \\
\text { the plate of food is obviously a plate of food } \\
\text { (right now I can only tell what it is in } \\
\text { context) } \\
\text { Put the pictures in chronological order, with } \\
\text { the no food, no drink first, then the clock \& } \\
\text { midnight } \\
\text { Good pic but can these kids tell time? }\end{array}$ \\
\hline 2 & $\begin{array}{l}\text { We will ask you } \\
\text { about all of the } \\
\text { medicines you } \\
\text { are taking }\end{array}$ & 71 & 18 & 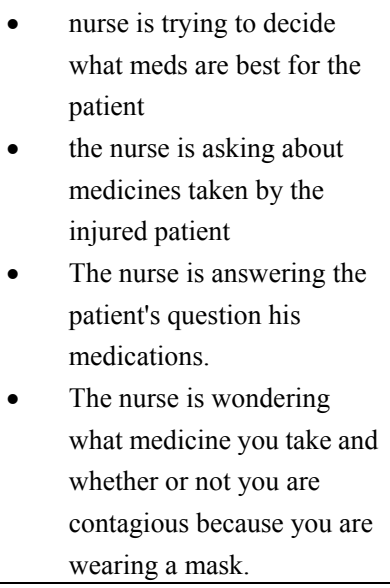 & $\begin{array}{l}\text { Put a message circle from the tiger with } \\
\text { three of the four and an x on the one he } \\
\text { doesn't take. } \\
\text { Take the mask off the patient- unless } \\
\text { people from other countries are used to } \\
\text { patients wearing masks instead of } \\
\text { doctors/surgeons } \\
\text { Maybe if you put a medication in the hand } \\
\text { of the patient, it would be more concrete }\end{array}$ \\
\hline 3 & $\begin{array}{l}\text { We will take a } \\
\text { small sample of } \\
\text { blood from a } \\
\text { vein in your arm }\end{array}$ & 66 & 17 & $\begin{array}{l}\text { - You will need a shot or give } \\
\text { blood. } \\
\text { You will get a needle prick } \\
\text { - } \quad \text { No we can draw blood. } \\
\text { bandages? Needles are } \\
\text { attracted to bandages? } \\
\text { Needles see bandages as an } \\
\text { emergency they need to } \\
\text { help overcome? } \\
\text { tire pump hopping on an } \\
\text { arm. }\end{array}$ & $\begin{array}{l}\text { - I'd put a little blood drop symbol on the } \\
\text { syringe to show blood is being drawn and } \\
\text { not an injection is being given. } \\
\text { It would probably be more clear if you just } \\
\text { showed the blood being drawn from the } \\
\text { appropriate spot } \\
\text { It might be helpful to include a picture of a } \\
\text { vial or several small vials of blood in a test } \\
\text { tube rack. It might also help to draw arrows } \\
\text { between the band-aid and the syringe, and } \\
\text { then, another from the syringe to the vial(s). }\end{array}$ \\
\hline 4 & $\begin{array}{l}\text { The information } \\
\text { we collect about } \\
\text { you during this } \\
\text { study will be kept } \\
\text { in a locked } \\
\text { research file }\end{array}$ & 66 & 23 & $\begin{array}{l}\text { We will keep your } \\
\text { information safe and } \\
\text { confidential. } \\
\text { Put documents which must } \\
\text { be secure and private in this } \\
\text { cabinet. } \\
\text { - Your file will be kept in a } \\
\text { secure file cabinet. } \\
\text { Files will not be shared with } \\
\text { anybody, personal } \\
\text { information will remain } \\
\text { confidential. }\end{array}$ & $\begin{array}{l}\text { - I would put a graphic of a patient on the } \\
\text { front of the folder so the person will know it } \\
\text { is about them. } \\
\text { It doesn't show any collected information - } \\
\text { add people collecting info } \\
\text { - Have a person talking with a dialogue box, } \\
\text { then cover the dialogue box with a lock } \\
\text { symbol, and then move it to a safe. }\end{array}$ \\
\hline
\end{tabular}




\begin{tabular}{|c|c|c|c|c|c|c|}
\hline 5 & $\begin{array}{l}\text { The purpose of } \\
\text { this research is to } \\
\text { understand how } \\
\text { the body } \\
\text { processes this } \\
\text { new medicine }\end{array}$ & 60 & 23 & $\begin{array}{l}\bullet \\
. \\
\bullet \\
\bullet \\
\bullet \\
.\end{array}$ & $\begin{array}{l}\text { If you take this medication, } \\
\text { it may not work, might } \\
\text { make you feel good, or may } \\
\text { make you sick. } \\
\text { Asking whether the person } \\
\text { ingested food, water or a } \\
\text { drug. } \\
\text { You will be divided into } \\
\text { three research groups. } \\
\text { When you take the } \\
\text { medicine tell us which } \\
\text { person you feel like. }\end{array}$ & $\begin{array}{l}\text { - there's no indication that research is } \\
\text { happening - it's all about the patient's } \\
\text { reaction. I'd add a person with a clipboard } \\
\text { at each line instead of a question mark. } \\
\text { Make the facial expressions more obvious, } \\
\text { really have to look to see the differences in } \\
\text { them. } \\
\text { Now that I know what you mean it makes } \\
\text { sense. But there has to be a better way to } \\
\text { show it. have the activity of the pill } \\
\text { radiating to the body not arrows to other } \\
\text { people. }\end{array}$ \\
\hline 6 & $\begin{array}{l}\text { We will take a } \\
\text { sample of your } \\
\text { saliva using a } \\
\text { small sponge on } \\
\text { a stick }\end{array}$ & 54 & 14 & $\begin{array}{l}\bullet \\
\bullet \\
\bullet \\
\bullet\end{array}$ & $\begin{array}{l}\text { The images show a swab } \\
\text { used to collect DNA from a } \\
\text { person's mouth. } \\
\text { Taking a swab for medical } \\
\text { purposes. } \\
\text { Someone will swab your } \\
\text { mouth with this little object } \\
\text { with a soft tip }\end{array}$ & $\begin{array}{l}\text { - A little overly graphic, could be a simpler } \\
\text { image } \\
\text { - } \quad \text { Make the saliva blue instead of brown } \\
\text { - } \quad \text { Show a hand holding the swab } \\
\text { thought }\end{array}$ \\
\hline 7 & $\begin{array}{l}\text { Participating in } \\
\text { this study is } \\
\text { voluntary }\end{array}$ & 48 & 28 & • & $\begin{array}{l}\text { Take the drug and we'll see } \\
\text { you later. } \\
\text { The doctor is offering the } \\
\text { patient a pill, and the patient } \\
\text { is refusing it. The patient is } \\
\text { walking away, and the } \\
\text { doctor is happy regardless. } \\
\text { There is no pressure to } \\
\text { participate and can happily } \\
\text { decline } \\
\text { After the doctor gives you a } \\
\text { prescription you will feel } \\
\text { better and be on your way }\end{array}$ & $\begin{array}{l}\text { - Show two subjects - one taking the study at } \\
\text { a computer and the other leaving. } \\
\text { I would add a question mark above the } \\
\text { 'doctor' } \\
\text { Perhaps add figures shaking their heads } \\
\text { 'yes' and 'no' with the 'yes' getting the pill } \\
\text { and the 'no' going on their way. } \\
\text { 'Voluntary' is definitely a word that is } \\
\text { understood easily in this picture. }\end{array}$ \\
\hline 8 & $\begin{array}{l}\text { We will take a } \\
\text { sample of your } \\
\text { saliva using a } \\
\text { small sponge on } \\
\text { a stick }\end{array}$ & 48 & 5 & $\begin{array}{l}\bullet \\
\bullet \\
\bullet \\
\bullet \\
\bullet \\
\bullet\end{array}$ & $\begin{array}{l}\text { A swab of your saliva will } \\
\text { be taken ( most likely for a } \\
\text { DNA sample ) } \\
\text { Clean your tongue when } \\
\text { you brush your teeth. } \\
\text { Checking for some kind of } \\
\text { infection } \\
\text { Having minor procedure } \\
\text { below the tongue or on } \\
\text { teeth } \\
\text { You have tooth decay }\end{array}$ & $\begin{array}{l}\text { - Draw the persons tongue } \\
\text { - It needs to show the swab touching saliva. } \\
\text { - There should be a picture in the middle with } \\
\text { the stick in the person's mouth. }\end{array}$ \\
\hline
\end{tabular}




\begin{tabular}{|c|c|c|c|c|c|c|}
\hline 9 & $\begin{array}{l}\text { The purpose of } \\
\text { this research is to } \\
\text { understand how } \\
\text { the body } \\
\text { processes this } \\
\text { new medicine }\end{array}$ & 48 & 42 & $\begin{array}{l}\bullet \\
\bullet \\
\bullet \\
\bullet \\
\bullet \\
\bullet\end{array}$ & $\begin{array}{l}\text { If you take the medication, } \\
\text { this shows where it will } \\
\text { focus its attention. } \\
\text { This is an oral medication. } \\
\text { The pill will go in mouth } \\
\text { thru lungs and into stomach } \\
\text { and dissolve their } \\
\text { When you take this tiny } \\
\text { pill, it will have big results } \\
\text { when it gets to your } \\
\text { stomach. } \\
\text { Do not take medication on } \\
\text { an empty stomach. }\end{array}$ & $\begin{array}{l}\text { - Perhaps instead of a magnifying glass, have } \\
\text { someone at a microscope looking at the pill. } \\
\text { The magnifying glass connotes a close-up } \\
\text { but not necessarily study. } \\
\text { Put a question mark on the handle of the } \\
\text { magnifying glass or on the pill. } \\
\text { Make the human a little darker, if you're } \\
\text { sick you can't make out light colors, who } \\
\text { wants to squint or bother making out the } \\
\text { pale silhouette of the human }\end{array}$ \\
\hline 10 & $\begin{array}{c}\text { Some of the } \\
\text { questions we ask } \\
\text { may make you } \\
\text { feel } \\
\text { uncomfortable }\end{array}$ & 47 & 24 & 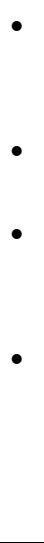 & $\begin{array}{l}\text { A doctor asking a patient } \\
\text { how they are feeling or } \\
\text { what they are feeling. } \\
\text { If you are sick and unsure } \\
\text { call the doctor immediately. } \\
\text { A young woman } \\
\text { questioning a man whom } \\
\text { looks to be embarrassed. } \\
\text { A woman who looks angry } \\
\text { is asking questions and the } \\
\text { other person is concerned } \\
\text { and dismayed about the } \\
\text { questions }\end{array}$ & $\begin{array}{l}\text { - } \\
\text { Badge on the one talking to communicate } \\
\text { she is a professional. } \\
\text { Maybe not have upside down question } \\
\text { marks, that makes it seem like the question } \\
\text { is confusing } \\
\text { Perhaps if the person inquiring held a } \\
\text { notepad or appeared to represent a doctor } \\
\text { who might be asking these embarrassing } \\
\text { questions. }\end{array}$ \\
\hline 11 & $\begin{array}{l}\text { The study } \\
\text { involves being } \\
\text { assigned to one of } \\
\text { two groups which } \\
\text { will be decided } \\
\text { randomly like } \\
\text { tossing a coin }\end{array}$ & 44 & 33 & $\begin{array}{l}\bullet \\
\text { • } \\
\bullet \\
\bullet \\
\bullet \\
\text { - }\end{array}$ & $\begin{array}{l}\text { You need to have money to } \\
\text { buy medicine } \\
\text { Flip a coin to see which } \\
\text { medicine you take -- } \\
\text { placebo or drug } \\
\text { The pill and capsule are the } \\
\text { same price } \\
\text { The assignment to a } \\
\text { particular treatment choice } \\
\text { will be random } \\
\text { You will be rewarded for } \\
\text { taking this study }\end{array}$ & $\begin{array}{l}\text { - Use equal signs instead of arrows } \\
\text { Show two groups of people one with a } \\
\text { heads label and one with a tails label. Have } \\
\text { a new patient standing with a health } \\
\text { worker. Show the worker flipping a coin to } \\
\text { choose which group the patient should go } \\
\text { in. } \\
\text { I would provide a bit more separation } \\
\text { between the two images of the coin (head } \\
\text { and tails). } \\
\text { This appears to be a US quarter - if the } \\
\text { study is being conducted internationally, } \\
\text { you may want to change the image of the } \\
\text { coin. }\end{array}$ \\
\hline
\end{tabular}




\begin{tabular}{|c|c|c|c|c|c|}
\hline 12 & $\begin{array}{l}\text { We will ask you } \\
\text { about all of the } \\
\text { medicines that } \\
\text { you are taking }\end{array}$ & 36 & 37 & $\begin{array}{l}\text { A medical person is going } \\
\text { to ask you about your } \\
\text { medical history. } \\
\text { Are you allergic to any } \\
\text { medications? } \\
\text { - The plus sign on the smiling } \\
\text { person's face tells me that } \\
\text { they are a healthcare } \\
\text { worker. The clipboard } \\
\text { depicts different types of } \\
\text { medications as if to say, } \\
\text { 'Which mediation is right } \\
\text { for me?' } \\
\text { You have no idea what is } \\
\text { inside all the medicines that } \\
\text { are prescribed to you } \\
\text { Medication and shots may } \\
\text { be involved but it's okay to } \\
\text { have questions. }\end{array}$ & $\begin{array}{l}\text { Maybe draw lines on the paper for places to } \\
\text { write the medications down } \\
\text { There should be two people - someone } \\
\text { asking (researcher) and someone providing } \\
\text { the information (subject) } \\
\text { - I think it should have a talk bubble from the } \\
\text { healthcare worker containing images of } \\
\text { prescription bottles and a question mark. } \\
\text { Perhaps group the items and form a sort of } \\
\text { list. }\end{array}$ \\
\hline 13 & $\begin{array}{l}\text { The purpose of } \\
\text { this research is to } \\
\text { understand how } \\
\text { the body } \\
\text { processes this } \\
\text { new medicine }\end{array}$ & 33 & 46 & $\begin{array}{l}\text { Prescriptions are a wakeup } \\
\text { call } \\
\text { The prescription will help } \\
\text { you think more clearly. } \\
\text { Your medication may have } \\
\text { an unknown and } \\
\text { unintended reaction inside } \\
\text { of your body. } \\
\text { If a person has questions } \\
\text { about their medicine, go to } \\
\text { where the arrow is pointing } \\
\text { to get information or help. } \\
\text { What will this RX do when } \\
\text { combined with a person? } \\
\text { Idea!!!! }\end{array}$ & $\begin{array}{l}\text { - Instead of using a light bulb show a } \\
\text { scientist with a clipboard } \\
\text { The equation and the light bulb could } \\
\text { probably be combined into a single image } \\
\text { that's more understandable. As it stands, it } \\
\text { looks like two separate ideas } \\
\text { - Show the medicine in the body } \\
\text { - } \quad \text { Maybe you can add the medication in a } \\
\text { circle in the body to show it 'processing'. }\end{array}$ \\
\hline 14 & $\begin{array}{l}\text { The purpose of } \\
\text { this research is to } \\
\text { understand how } \\
\text { the body } \\
\text { processes this } \\
\text { new medicine }\end{array}$ & 31 & 41 & $\begin{array}{l}\text { - } \\
\text { Pills will help that circled } \\
\text { portion of your heart. } \\
\text { This medication will } \\
\text { dissolve when it reaches the } \\
\text { lungs. } \\
\text { - } \quad \text { Swallow the tablet whole. } \\
\text { - Taking this medicine might } \\
\text { cause an upset stomach. }\end{array}$ & $\begin{array}{l}\text { Perhaps there could be a person with an } \\
\text { inspector's jacket and a magnifying glass } \\
\text { looking at the person's organ systems to } \\
\text { indicate that these are the subject of } \\
\text { investigation } \\
\text { I would change the organs to a } \\
\text { manufacturing facility and then show a } \\
\text { different looking pill with a question mark } \\
\text { at the end } \\
\text { - Make the med go all the way thru the body }\end{array}$ \\
\hline
\end{tabular}




\begin{tabular}{|c|c|c|c|c|c|c|}
\hline 15 & $\begin{array}{l}\text { Your sample will } \\
\text { be de-identified } \\
\text { prior to sending } \\
\text { it to the } \\
\text { laboratory }\end{array}$ & 24 & 44 & $\begin{array}{l}\bullet \\
\bullet \\
\bullet\end{array}$ & $\begin{array}{l}\text { Top of a prescription } \\
\text { bottle-complete the name } \\
\text { address and personal } \\
\text { information label. } \\
\text { They look like labeling } \\
\text { options for medical } \\
\text { specimens } \\
\text { The info on the labels are } \\
\text { not all the same. }\end{array}$ & $\begin{array}{l}\text { Blurring of letters, or pixelating would } \\
\text { bring the message across much more } \\
\text { clearly } \\
\text { - I think if they would show where it is going, } \\
\text { for example write lab on top of the second } \\
\text { item. } \\
\text { Show a picture of a lab with the second } \\
\text { bottle and a picture of a doctor's office with } \\
\text { the first. } \\
\text { Maybe put an X through the information } \\
\text { lines or actually write the words "info will } \\
\text { not be visible when sample is passed on" or } \\
\text { something to that effect. }\end{array}$ \\
\hline 16 & $\begin{array}{l}\text { The medicine we } \\
\text { give you may } \\
\text { make you feel } \\
\text { lightheaded }\end{array}$ & 24 & 53 & $\begin{array}{l}\bullet \\
\bullet \\
\bullet \\
\bullet\end{array}$ & $\begin{array}{l}\text { A person taking medicine, } \\
\text { then feeling dizzy. } \\
\text { Drug overdose. } \\
\text { Food making someone sick. } \\
\text { The side effects of taking } \\
\text { medication. }\end{array}$ & $\begin{array}{l}\text { - } \\
\text { - } \quad \text { Maybe have the dotted lines end in an } \\
\text { arrow, and perhaps comment on the } \\
\text { likelihood of each possible outcome. } \\
\text { - His head should be detached slightly like a } \\
\text { balloon floating and add clouds. }\end{array}$ \\
\hline 17 & $\begin{array}{l}\text { You will not be } \\
\text { allowed to } \\
\text { participate in this } \\
\text { study if you have } \\
\text { used recreational } \\
\text { drugs in the past } \\
30 \text { days }\end{array}$ & 23 & 49 & $\begin{array}{l}\bullet \\
\bullet \\
\bullet \\
\bullet \\
\bullet\end{array}$ & $\begin{array}{l}\text { A sign to not take any } \\
\text { medicines and or drugs. } \\
\text { Consuming drugs is wrong } \\
\text { Don't use street drugs } \\
\text { No drugs for one month } \\
\text { Substance free zone }\end{array}$ & $\begin{array}{l}\text { I understood the not using drugs, but didn't } \\
\text { understand the } 30 \text { days part. } \\
\text { The cycles of the moon are a bit confusing, } \\
\text { try using a calendar } \\
\text { - It seems like it's prohibiting use now or in } \\
\text { the future, not in the past } 30 \text { days. } \\
\text { Put the number } 30 \text { on the image }\end{array}$ \\
\hline 18 & $\begin{array}{l}\text { This is a } \\
\text { double-blind } \\
\text { study meaning } \\
\text { that neither you } \\
\text { nor your study } \\
\text { doctor will know } \\
\text { the treatment } \\
\text { group you have } \\
\text { been assigned to }\end{array}$ & 21 & 64 & $\begin{array}{l}\bullet \\
\bullet \\
\bullet \\
\bullet \\
\bullet \\
\bullet\end{array}$ & $\begin{array}{l}\text { You will be hand selected } \\
\text { for your study. } \\
\text { God is just toying with us } \\
\text { (sorry, I'm in the middle of } \\
\text { an existential crisis) } \\
\text { Patients/study participants } \\
\text { will be put into a room or } \\
\text { hotel. } \\
\text { A doctor and test subject } \\
\text { will be paired together } \\
\text { randomly } \\
\text { The left hand appears to be } \\
\text { an individual that is } \\
\text { experiencing ill health. The } \\
\text { right hand appears to be } \\
\text { holding a security guard or } \\
\text { police officer. The arrows } \\
\text { appear to be indicating that } \\
\text { the patient will be under } \\
\text { guard }\end{array}$ & $\begin{array}{l}\text { - Insert a question mark somewhere to } \\
\text { distinguish the 'not knowing' portion } \\
\text { Put blindfolds on both the doctor and the } \\
\text { person being studied. } \\
\text { I would begin by not using larger than life } \\
\text { hands to suspend human sized figures ten } \\
\text { feet from the floor. I'm not even feeling ill } \\
\text { and looking at this image kind of creeped } \\
\text { me out. }\end{array}$ \\
\hline
\end{tabular}




\begin{tabular}{|c|c|c|c|c|c|}
\hline 19 & $\begin{array}{l}\text { Your sample will } \\
\text { be de-identified } \\
\text { prior to sending } \\
\text { it to the } \\
\text { laboratory }\end{array}$ & 19 & 47 & $\begin{array}{l}\text { - It is a vial of blood drawn } \\
\text { with identifying } \\
\text { information. } \\
\text { A round tube used when } \\
\text { drawing blood of patient. A } \\
\text { label to be placed on the } \\
\text { blood containing tube of } \\
\text { patient. A lab tube used to } \\
\text { hold blood due to a } \\
\text { requested test by physician. }\end{array}$ & $\begin{array}{l}\text { - I would prefer the label indicate that it is } \\
\text { de-identified instead of being blank. } \\
\text { show personal information on the left, and } \\
\text { just a code on the right } \\
\text { - Picture of person with lab coat on writing } \\
\text { the information on the tube }\end{array}$ \\
\hline 20 & $\begin{array}{l}\text { The medicine we } \\
\text { give you may } \\
\text { make you feel } \\
\text { lightheaded }\end{array}$ & 13 & 49 & $\begin{array}{l}\text { A person feeling strange, } \\
\text { floating, light-headed. } \\
\text { Careful or you will get sick } \\
\text { from airborne germs } \\
\text { - } \quad \text { Either a person has his } \\
\text { heads in the clouds or ate } \\
\text { something possibly hot. } \\
\text { - Hazards of smoking and } \\
\text { drugs } \\
\text { I think this is explaining } \\
\text { that taking a certain } \\
\text { medication can make you } \\
\text { feel sick. }\end{array}$ & $\begin{array}{l}\text { - Change the picture so it doesn't look as if } \\
\text { they are breathing in smoke. } \\
\text { Give the person some eyes. And maybe put } \\
\text { stars in them or spirals to indicate dizziness } \\
\text { or lightheadedness. The empty eye sockets } \\
\text { are frightening. } \\
\text { I would show a this person taking a pill to } \\
\text { get the idea across better }\end{array}$ \\
\hline 21 & $\begin{array}{c}\text { Some of the } \\
\text { questions we ask } \\
\text { may make you } \\
\text { feel } \\
\text { uncomfortable }\end{array}$ & 11 & 51 & $\begin{array}{l}\text { - A language barrier } \\
\text { - The person is hearing } \\
\text { information from someone } \\
\text { but does not understand that } \\
\text { info and feels shame about } \\
\text { it. } \\
\text { A person that looks sick and } \\
\text { also has a dialogue chart } \\
\text { with question marks } \\
\text { The thought bubble } \\
\text { provides question marks as } \\
\text { if someone was in deep } \\
\text { thought. }\end{array}$ & $\begin{array}{l}\text { A picture of someone writing on a pad } \\
\text { along with the question marks } \\
\text { Allowing us to see where the questions } \\
\text { coming from would help } \\
\text { If the person weren't blue-green but still } \\
\text { blushing they may look more } \\
\text { uncomfortable rather than sick, which } \\
\text { should help communicate the concept } \\
\text { better }\end{array}$ \\
\hline 22 & $\begin{array}{l}\text { There will be no } \\
\text { direct benefit to } \\
\text { you for } \\
\text { participating in } \\
\text { this study, being } \\
\text { in this study will } \\
\text { help doctors treat } \\
\text { future patients } \\
\text { better }\end{array}$ & 9 & 89 & $\begin{array}{l}\text { - Look at the light while the } \\
\text { eye doctor checks your eyes } \\
\text { a nice male happy doctor } \\
\text { will examine anything } \\
\text { involving your head } \\
\text { - The doctor is going to use } \\
\text { equipment to closely } \\
\text { inspect the patient. } \\
\text { The doctor is going to } \\
\text { examine you with his eyes } \\
\text { closed, so you should close } \\
\text { your eyes too. }\end{array}$ & $\begin{array}{l}\text { Provide thinking circle with various people, } \\
\text { babies, little kids, adults, etc. } \\
\text { I would include something to indicate } \\
\text { knowledge is being passed on, like books or } \\
\text { test tubes. } \\
\text { - } \\
\text { I guess I would have a doctor observing a } \\
\text { patient with a line of patients lined up in the } \\
\text { background. This would show that the their } \\
\text { participation will benefit others. } \\
\text { I think maybe have a picture of a bunch of } \\
\text { smiling faces with different nationalities } \\
\text { and ages. }\end{array}$ \\
\hline
\end{tabular}




\begin{tabular}{|c|c|c|c|c|c|}
\hline 23 & $\begin{array}{l}\text { With your } \\
\text { permission we } \\
\text { will keep the } \\
\text { samples you } \\
\text { provide us for } \\
\text { future research }\end{array}$ & 9 & 83 & $\begin{array}{l}\text { Evil scientists collecting } \\
\text { specimens. } \\
\text { Aliens are filling your } \\
\text { prescriptions. } \\
\text { I believe this is a way of } \\
\text { explaining warning labels } \\
\text { or to read instructions on } \\
\text { taking this medication } \\
\text { carefully before taking. } \\
\text { It is a study to research } \\
\text { what bacteria are in } \\
\text { different specimens } \\
\text { This medication is made } \\
\text { from bees. }\end{array}$ & $\begin{array}{l}\text { - Remove the bug/creature, maybe use a } \\
\text { physician or nurse putting the sample in a } \\
\text { cabinet. } \\
\text { - Use the samples but put them in a freezer } \\
\text { with a lock and flip a calendar page to } \\
\text { several years ahead. } \\
\text { - Show test tubes with blood samples and } \\
\text { maybe a form showing a signature to relay } \\
\text { that permission for these tests is approved } \\
\text { by the patient. } \\
\text { Have two people shaking hands to indicate } \\
\text { agreement. And then show some kind of } \\
\text { storage container....or shelf or closet. }\end{array}$ \\
\hline 24 & $\begin{array}{l}\text { You will not be } \\
\text { allowed to } \\
\text { participate in this } \\
\text { study if you have } \\
\text { used recreational } \\
\text { drugs in the past } \\
30 \text { days }\end{array}$ & 8 & 67 & $\begin{array}{l}\text { A clear sign not to smoke } \\
\text { anything. } \\
\text { Do not smoke tobacco } \\
\text { while taking this } \\
\text { medication. }\end{array}$ & $\begin{array}{l}\text { A symbol of drugs need to be added, you } \\
\text { cannot tell what he is smoking. Also add } \\
\text { something about } 30 \text { days, maybe labeled } \\
\text { below. } \\
\text { - A time limit and more than just a cigarette } \\
\text { needs to be shown }\end{array}$ \\
\hline 25 & $\begin{array}{l}\text { The study doctor } \\
\text { may stop the } \\
\text { study at any time }\end{array}$ & 5 & 84 & $\begin{array}{l}\text { - Check heart rate. } \\
\text { - Stop until the doctor sees } \\
\text { you. } \\
\text { - Don't use your head phones } \\
\text { at 12:15. } \\
\text { - Stop what you are doing, } \\
\text { listen with stethoscope, this } \\
\text { is important. } \\
\text { - } \\
\text { Danger. Don't use blood } \\
\text { pressure machines. }\end{array}$ & $\begin{array}{l}\text { - I would use a red traffic light for stop. I } \\
\text { would use an outline of a person wearing a } \\
\text { white coat and stethoscope to be the doctor. } \\
\text { Perhaps two figures would be more useful, } \\
\text { one showing a patient with a red hand } \\
\text { stopping a doctor, followed by the patient } \\
\text { pointing to their clock or watch with the } \\
\text { doctor showing agreement. } \\
\text { To indicate that the doctor may stop the } \\
\text { study, I would show an image of a doctor, } \\
\text { pointing to the red light, indicating they are } \\
\text { stopping the study. To indicate that the } \\
\text { study has ended, show a study participant } \\
\text { and doctor waving goodbye to each other, } \\
\text { with the study participant halfway out of } \\
\text { the doorway. }\end{array}$ \\
\hline
\end{tabular}

\section{Figure Legend}

Preliminary images created by students exploring the various research-related concepts detailed in the table. 